\title{
Development of Stylistics Course Based on YouTube Video
}

\author{
Elly Delfia 1, Fadlillah $^{2}$, M.Yunis ${ }^{3}$
}

\author{
${ }^{1}$ Indonesia Department, Andalas University, Indonesia \\ 2 Indonesia Department, Andalas University, Indonesia \\ 3 Indonesia Department, Andalas University, Indonesia \\ *Corresponding author. Email:rudelfia@gmail.com
}

\begin{abstract}
Stylistics is one of the compulsory courses in the Indonesian Language Department, Faculty of Humanities, Andalas University. Stylistics is the subjects dual paradigm (literature and linguistics) that needs to be developed because of a lack of interest by the students. The development of this course aims to train students to be able to solve problems systematically and procedurally and to sharpen students' creativity, innovation and self-confidence. This case is matched to the vision and mission of the Faculty of Humanities and mission of quality assurance aspired by Andalas University to become a world-class university. The output of this course development is the RPS followed by KKNI Standard, assignments video and students' exams uploaded on YouTube, and articles presented at the International Conference on Educational Development Quality Assurance (ICED-QA) Andalas University in October 2020.
\end{abstract}

Keywords: Development, stylistics, youtube video

\section{INTRODUCTION}

Stylistics is one of the compulsory subject in the Indonesian Literature Department at the Faculty of Humanities, Andalas University. This subject is offered for third-year or six-semester students and has 2 credits. The subject is a type of course that combines two fields of study in the Indonesian Department, these are linguistics and literature. This subject is called dual paradigm because it discusses two scientific paradigms, literature and linguistics. Delfia (2019) states that several researches have been conducted to this course, such as stylistics, sarcasm, and hate speech. [1]

According to Junus in Fitri [2], the essence of stylistics is the study of the use of linguistics in literary works. Nurgiyantoro [3] defines stylistics or stiles as a language style or way of pronouncing language in prose or how an author expresses something to be put forward. Stiles is related to the formal language features, such as words choice, sentence structure, figurative language forms, rhetorical tools and the use of cohesion. Fitri [2] stylistics is to be a part of literary science, more narrowly, linguistics in relation to aspects of aestetics in the field of language and literature.

The history of stylistic cannot be inseparably from rhetoric. Historically, the rhetoric comes first. Rhetoric is the art and theory of public speaking. In brief, the origin of stylistics derives from rhetoric [4]. So far, the stylistics is two credits course with sixteen meetings; face-to-face fourteen meetings and two meetings for examinations (the mid and final test). After course development, the time and credit will be increased from 2 to 3 hours and 2 credits to 3 credits in next semester.

The students who take the stylistics course can write a thesis by choosing the linguistic stylistics or the literary stylistics. The development of the YouTube video-based stylistics is an important to develop this course become more interesting and attractive for students. Then, this course is able to sharpen critical thinking, communication, and problem solving. 


\subsection{Related to Work}

The course concerns on stylistics, types of language style, the relationship between stylistics and aesthetics, hermeneutics, rhetoric, and semiotics. The relationship of stylistics with others, especially rhetoric, is very important to be developed more deeply because it can train students to improve speaking skills. The stylistic is applied to objects of literary works in the form of poetry, short stories, drama scripts, and novels. Stylistics also cover the style of language in the mass media and society. The development of a YouTube video-based stylistics course can improve the quality of student skills. Students who have good skill will automatically increase the teaching quality in the university.

\subsection{Our Contribution}

This research provides contribution preferably to students to understand better the literary studies from stylistic point of view in Indonesian Department, Faculty of Humanities, Andalas University, especially linguistics and literature. The development of this course also contributes to improve the thinking abilities, language skills, and literary texts analysis. The result of the development of this course is a video with 10 to 15 minutes duration. The video contains assignments and final examination of literary texts analysis, such as poetry, short stories, novels. Those text are analyzed with a stylistic approach, such as imagery, language style, semiotics, hermeneutics, and heuristic or comprehensive analysis of literary works. The analysis of literary works are uploaded on the YouTube and each video is open for public. The public will also get new insight from watching the video.

In addition, this research also give benefit for RPS and teaching learning development in Indonesian Department, Faculty of Humanities, Andalas University. Indirectly, this research give significant contibution to teaching quality improvement in Andalas University during covid 19 pandemic period.

\subsection{Paper Structure}

The article consists of three parts. Part one article contains the position and importance of the stylistic course in the Indonesian Department, Faculty of Humanities, Andalas University. It relates to institutional development, authorship structures, and methods. Part two discuss the background in developing courses based on YouTube video and development results. Part three is conclusion of course development activities based on the YouTube video.

\subsection{Method}

The resercher uses the Student Centered Learning innovation and divides students into small group discussion (SGD). Roberts [5] states that studentcentered learning therefore, requires that students get actively involved in the learning process and take responsibility for their own learning. Each topic in the syllabus is discussed together in groups and then presented by each group at online class. In SGD method, the students are allowed to both discussion and presentation, besides students are also guided to create YouTube video content about the analysis of literary works using a stylistic approach. This activity encourages students' self-confidence to explain topic through videos and to share knowledges with YouTube audiences.

\section{RESULT AND DISCUSSION}

The development of stylistics is carried out based on the students' scores monitoring each semester and students' interest in choosing stylistics as topic for thesis writing. Writing a thesis as one of requirements in completing a bachelor's degree for students, it is also a means of students learning success in higher education. The low interest in this subject becomes a major reason for the development of this course.

The development is began first by revising and evaluating the previous Semester Learning Plan (Rencana Pembelajaran Semester or RPS) and syllabus. The material in the RPS and syllabus are evaluated and refined to help students learning process, besides to support the vision and mission of the Faculty of Humanities in developing quality assurance, as Andalas University goal to be world-class university.

This course is expected more applicable, reliable to support language skills (soft skills) Indonesian Department students who are ready to compete in the career and work. The using of YouTube as teaching media is very representative with the students today.

\subsection{Teaching Materials Development}

The lecturer developes teaching materials such as textbooks, reference books, and power points which these digital teaching materials or videos uploaded on YouTube. Next, the students are given to do assignments to analyze poetry or a short story.

\subsection{Assessment Measure Learning Outcomes}

The subjects of this research are students who have good comprehension skills, the ability to explain and distinguish well about language styles and how to use them. The students can apply various stylistic theories to analyze literary works by creating video content and uploading them on YouTube. Based on the video assignments, the lecturer organizes the components of assessment to get score. If the initial assessment component, the soft skill assessment criteria (skills) is $25 \%$, after development, this score will be increased to $30 \%$ by reducing $5 \%$ per cent of the middle test score. The percentage of final test is equalized to previous score. There are additional points for creativity and skill in creating YouTube video. The details score before and 
after course development can be seen on the table below:

Table 1:

\section{Assessment Criteria before the Development of the Statistics Course}

\begin{tabular}{|c|c|c|}
\hline N & Assessment Components & Score \\
\hline \multicolumn{2}{|l|}{ 1. Assesment of Result } \\
\hline A & Middle Test & $35 \%$ \\
\hline B & Final Test & 40 \\
\hline 2. & Assesment of Process \\
\hline 1 & Intrapersonal skill & $10 \%$ \\
\hline 2 & Interpersonal softskill & $15 \%$ \\
\hline & Total & $100 \%$ \\
\hline
\end{tabular}

Table 2:

Assessment Criteria after the Development of the Statistics Course

\begin{tabular}{|r|l|r|}
\hline $\mathrm{N}$ & Assessment Components & \multicolumn{1}{|c|}{ Score } \\
\hline \multicolumn{2}{|c|}{ 1. Assesment of Result } \\
\hline A & Middle Test & $30 \%$ \\
\hline B & Final Test & $40 \%$ \\
\hline 2. & Assesment of Process \\
\hline 1 & Intrapersonal skills & $15 \%$ \\
\hline 2 & Interpersonal softskill & $15 \%$ \\
\hline & Total & $100 \%$ \\
\hline
\end{tabular}

\subsection{Methodology and Strategy for Output Achievement}

The development of YouTube video-based stylistics courses is an effort to create applicable courses in improving the quality of learning in higher education, especially in the Indonesian Department, Faculty of Humanities, Andalas University. The development of stylistics courses in the Indonesian Department, Faculty of Humanities, Andalas University by utilizing YouTube also supports the government's policy, a study from home (SFH) due to the Covid-19 pandemic.

This research conducts the SCL (student- centred learning) learning method which begins with an explanation of the topic at every meeting on the YouTube, power points, and reference book. The teaching materials are designed in accordance with RPS and syllabus and discussed on whatapps group class during the study from home (SFH).

The students are given exercises and assignments. They are also given examples of stylistic analysis models. Then, the students learn to choose one of the literary works and analyze with a stylistic approach, such as image theory, the figure of speech or language style, semiotics, hermeneutics, and etc. Then, the students' assignment are checked and evaluated by the lecturer. Then, the students correct their assignments. After assignment finished, the tasks are ready to be uploaded on their own YouTube channel.

Furthermore, they can share the YouTube link for public to watch and enjoy. The audience also gets new enlightenment and knowledge from the video. Thus, this strategy is executed to the obtain outcomes of developing this course. The result of this research is written in an article that will be presented at the International Conference on Education Development and Quality Assurance III (ICED-QA III) Andalas University in October 2020. This article will also published on Atlantis indexed- proceeding conference.

\subsection{Results of the Development of the Stylistics Course}

The development of this course is performed by using YouTube, as one of the popular media today for students. Iwantara [6] in his researches said YouTube video is superior compared to real media and chart media in learning motivation. By utilizing YouTube videos, lecturers also can make teaching materials in the form of videos that are uploaded on YouTube and share the link to students. The students can get teaching material there.

The students also create attractive videos about literary work analysis with a stylistic approach. The video discusses one of the topics that have been assigned by the lecturer. Then, it uploads on the YouTube channel. By creating this content, the students prepare themselves by reading and understanding the discussed material. The students also build awareness themselves when the videos can be accessed by public and watched by many people. Therefore, they will do the best for the assignment.

The choose topic that will be designed into a videos with duration of 10 to 15 minutes are literary work, such as poetry and short story. The development of this course is implemented in the even semester of 2019/2020 from March to May 2020. Each student must create two videos then upload on YouTube channels. First video is assignment the the second one is substitution of final semester test.

The lecture also provides teaching material video as the learning outcomes in stylistics courses development based on YouTube. Students also upload assignments that have been guided by the lecturer analysis through their YouTube channels. Next, the students shared their 
assignment link on YouTube in the online class. The other students can watch and correct their works on YouTube. They also share, like, and subscribe each other as a proof of appreciation for their hard work in making assignments and final semester exams in video YouTube. These are some video links from the development of the stylistics course.

$\begin{array}{ll}\text { 1. } & \text { Elly Delfia https://youtu.be/GMdbp-p3SZw } \\ \text { 2. } & \text { Rahma Yulia } \\ & \text { Sari http://youtu.be/pB4Kk8_MSq4 } \\ \text { 3. } & \text { Aisya Putri } \\ & \text { Rizano http://youtu.be/xk63vqNSSSY } \\ \text { 4. } & \text { Tri Ananda Putri } \\ & \text { Utami https://youtu.be/tMW854uWJSk }\end{array}$

5. Muhammad Alfarizi https://youtu.be/R2LMomGz5ok

6. Muhammad
https://youtu.be/mu0qfMI28cQ

7. Erlyn Deyani https://youtu.be/Z5ruhyDXVqc

8. LatifaFatnihttps://youtu.be/7HLfCpYVOo0

9. Refaldo https://youtu.be/nUrxHYegxAM

10. Indah Sapitri https://youtu.be/e3goLtTA2hY

11. Radika Sawitri https://youtu.be/FqbZ-y99YSQ

12. Maya Risani https://youtu.be/bTNabXUwrWg

13. Johan Padukahttps://youtu.be/S0xU7-V3MDk

14. Ulfatun
https://youtu.be/8zGT1IKcfDk

The development of the stylistics course in the Indonesian Department, Faculty of Humanities, Andalas University is expected to become applicable and reliable course to support the skills or soft skills for Indonesian Department students, especially to improve language skills that are able to compete as professional. Language skills and self-confidence are the significant capital to produces graduates in career. Moreover, this course help the students to train themselves to be confident and share insights with the public. Through development of YouTube video-based courses, it can increase students' grades to be better than the previous semester. Besides, the development of this course also changes the RPS which remains in the old format into an RPS based on Indonesian National Qualifications Framework (KKNI) standard. Matched to Savitri [7] in her statement on the "Review of courses in the KKNI- based on Curriculum Structure, Indonesian Literature Study Program, UNESA", the backround of development of stylistics course based on KKNI according to presidential regulation number 8 of 2012. KKNI is a statement of the quality of Indonesia's human resources in accordance with the qualification gap stated by learning outcomes (ristek.brin.go.id) [9].The development of a YouTube video-based stylistic course produces an RPS (Semester Learning Plan) as the CPL KKNI standards or Learning Outcomes as in the table below:

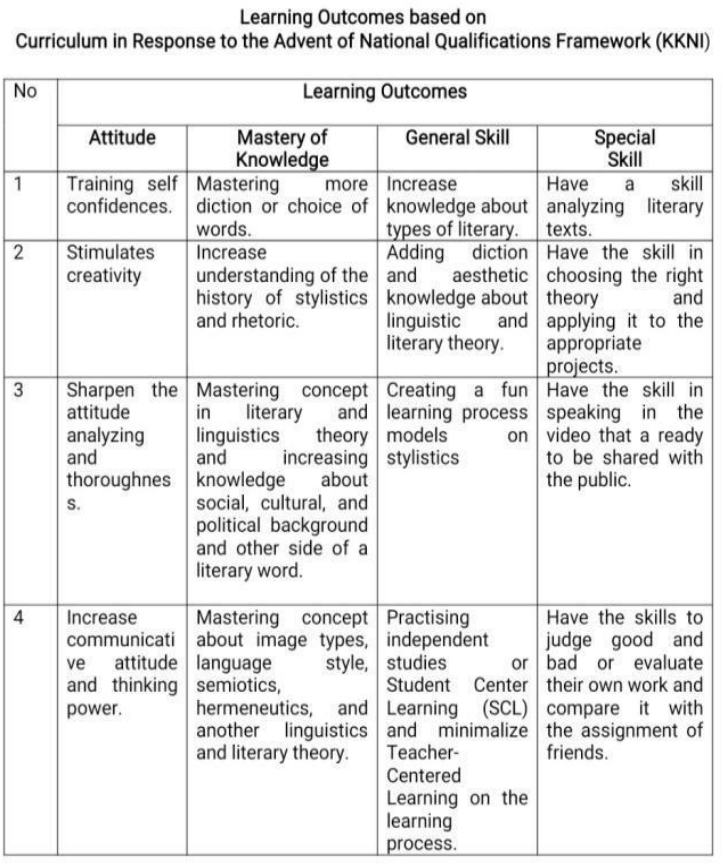

First, attitudes are personality traits or behaviour that are owned by individuals. Experts have different views on attitudes. Rahmat [9] provides empathy for attitudes. These definitions including a) Attitude is the tendency to act, think, and feel that someone is the best in dealing with objects, ideas, and situations or situations of value. The objects can be people, places, ideas or group situations. b) Attitude is also defined as appropriate or appropriate assisting power or motivation. The student's attitudes that can be formed from the development of a YouTube video-based stylistic course are confidence, creativity, analyzing skills, and speaking or communication skills, and thinking power.

Second, knowledge capabilities relates to how to improve insights and its impact to way of thinking, attitude, and performance. This capability of YouTube video-based stylistic course development can improve diction, understand about the stylistics and rhetoric history, master stylistics linguistic and stylistic literary concept, and deal with image theory, the figure of speech, style, semiotics, hermeneutics, and other.

Third, general skills. Ministry of Research, Technology and Higher Education of Indonesia states general skill are general abilities and responsibilities according to the level and type of higher knowledge or education level [10]. General skills from the development of a YouTube video-based stylistic course are to increase comprehension about types of literary, to provide 
aesthetic knowledge, linguistics and literary, to create fun learning process on stylistics, and practice students centered learning (SCL) method.

Fourth, specific skills are specific work abilities related to the field of study or study program. The students will be benefitted speciall skills from this development course. The students are able to analyze literary texts with some stylistics theories; they also find decent theory for objects; the students are good in communication skills and explain learning topic on the video YouTube comprehensively, and the students are able to evaluate critically their works each other.

\section{CONCLUSION}

The results of the development of this YouTube videobased course are as follows:

1. RPS and syllabus are compatible KKNI standards.

2. To increase students' capabilities in soft skills. Students can develop attitudes, mastery of knowledge, general skills, and comprehensive skills related to stylistics course.

3. Videos of student assignments and exams upload on the YouTube channel.

4. The article will be published in the ICED-QA proceedings of Andalas University in 2020.

Students train themselves to solve problems systematically and procedurally. This case is compatible with the vision and mission of the Faculty of Humanities, Andalas University as a delivery and development mission (quality assurance) as in Andalas University goal to be a world-class university.

\section{ACKNOWLEDGMENT}

This work is supported by Quality Assurance in Education of Andalas University (2020) and Faculty of Humanities Andalas University, Indonesia.

\section{REFERENCES}

[1] Delfia, Elly \& M.Yunis. 2019. Sarcasm and Hate Speech on Democratic contest in Indonesia Study of Post-Truth Stylistics. Padang:Andalas University.

[2] Fitri, Rahayu. 2016. Stylistics of Teaching Material. Yogyakarta:Deepublish.

[3] Nurgiyantoro, Burhan. 2017. Stylistics. Yogyakarta: Gadjah Mada University Press.

[4] Ratna, Nyoman Kutha. 2014. Stylistics (Poetic, Language, Literary and Cultural Studies). Yogyakarta: Student Library.

[5] Roberts, Nathan. 2016. Small Group Teaching: Methods \& Techniques.cardiff.ac.uk.

[6] Iwantara, I.W. \& I.W. Sadia, I. W. Suma. 2014. The Influence of Using YouTube Video in
Science Learning on students' learning motivation and understanding of concepts. Singaraja:e-journal GaneshaUniversityofEducation.

[7] Savitri, Agusniar Dian and Kisyani Laksono. 2017. "Review of courses in the KKNI-based curriculum structure, Indonesian Literature Study Program,

UNESA".LinguaJournal.journal.unessa.ac.id

[8] Cooperation and Public Relations of UTM. 2018. Learning Training Based on the National Qualifications Framework (KKNI). www.ristekbrin.go.id.

[9] Rahmat, Jalaludin. 2007. Psychology of Communication.Bandung:PTRemajaRosdakarya

[10] Ministry of Research, Technology, and Higher Education. 2017. Sign of Preparation Learning Achievement.www.ristekdikti.go.id. 